\title{
Caffeine citrate enhanced cisplatin antitumor effects in osteosarcoma and fibrosarcoma in vitro and in vivo
}

\author{
Kensaku Abe, Norio Yamamoto, Katsuhiro Hayashi, Akihiko Takeuchi* [D and Hiroyuki Tsuchiya
}

\begin{abstract}
Background: While multiagent chemotherapy has dramatically improved the prognosis of sarcoma, the novel chemotherapeutics have hardly developed over the past 30 years. Caffeine can induce apoptosis, delays in cell cycle progression and can enhance the cytocidal effects of anti-cancer agents. Citrate has been reported to enhance the cytocidal effect of cisplatin in gastric cancer in vitro. However its effect in sarcoma cells had not been reported.

Methods: This study was designed to evaluate whether the addition of caffeine, citrate, or caffeine citrate to cisplatin improved its cytocidal effect (cell survival, proliferation, and apoptosis) on human osteosarcoma (HOS), human fibrosarcoma (HT1080) and murine osteosarcoma (LM8) cell lines. We also tested the various combinations in a mouse heterotopic transplantation model in vivo. In cell survival assay, combination index (Cl) of caffeine citrate was calculated as a combination of anhydrous caffeine and citric acid, and the synergy was evaluated $(\mathrm{Cl}<1.0)$.
\end{abstract}

Results: In all cell lines, cisplatin combined with caffeine citrate significantly reinforced the anticancer effect compared with cisplatin alone, combination of cisplatin and anhydrous caffeine, and combination of cisplatin and citric acid. Moreover, $\mathrm{Cl}$ was $<1.0$ in all conditions. The anticancer agent reinforcement effect of caffeine citrate was synergy of anhydrous caffeine and citric acid. In cell proliferation and cell cycle assay revealed that caffeine citrate had most strong effect as a combination drug than caffeine and citric acid in inducing G0/G1 cell-cycle arrest with subsequent suppressed cell proliferation. In mitochondrial depolarization and caspase 3/7 activity assay revealed that caffeine citrate had most strong effect as a combination drug than caffeine and citric acid in apoptosis associated with decreased mitochondrial membrane potential. In vivo, three different drug concentrations were tested, and cisplatin combined with caffeine citrate was found to have the strongest antitumor effect.

Conclusions: This is the first report demonstrating that caffeine citrate has a significantly greater potentiating effect on cisplatin than adding either caffeine or citric acid. The combination of cisplatin with caffeine citrate is a novel treatment that might hold promise for improving the outcome of osteosarcoma and fibrosarcoma, which up till now has generally not responded well to chemotherapy.

Keywords: Caffeine citrate, Chemotherapy, Osteosarcoma, Fibrosarcoma, Cancer

\footnotetext{
* Correspondence: a_take@med.kanazawa-u.ac.jp

Department of Orthopaedic Surgery, Graduate School of Medical Sciences,

Kanazawa University, 13-1 Takara-machi, Kanazawa 920-8641, Japan
}

(c) The Author(s). 2019 Open Access This article is distributed under the terms of the Creative Commons Attribution 4.0 International License (http://creativecommons.org/licenses/by/4.0/), which permits unrestricted use, distribution, and reproduction in any medium, provided you give appropriate credit to the original author(s) and the source, provide a link to the Creative Commons license, and indicate if changes were made. The Creative Commons Public Domain Dedication waiver (http://creativecommons.org/publicdomain/zero/1.0/) applies to the data made available in this article, unless otherwise stated. 


\section{Background}

Osteosarcoma is a malignant primary bone tumor occurring mainly in adolescents and young adults [1]. The 5-year survival is approximately 70\% [2-4]. However, patients with metastatic disease at diagnosis or with recurrent disease have a 5-year survival of only $20 \%$ [5]. Metastases most commonly affect the lung and are the most common cause of death in patients with osteosarcoma [6]. First-line therapy for this malignancy consists of high-dose methotrexate, cisplatin, doxorubicin, and ifosfamide. However, dose-intensive chemotherapy regimens with these agents have not improved outcomes [7].

Soft tissue sarcoma can arise in almost any anatomic site, including the extremities (60\% of cases), thorax, abdomen, retroperitoneum, or head and neck [8]. More than 50 histologic subtypes of soft tissue sarcoma have been identified and are defined by the World Health Organization classification, each with a different treatment response and prognosis $[9,10]$. The 5-year survival of patients with the entire range of soft tissue sarcoma remains about $50 \%$, which is far from satisfactory $[8,11]$. In advanced soft tissue sarcoma that is either unresectable or metastatic, the 5-year survival reportedly ranges from 20 to $50 \%$ [8]. Drugs used in first-line treatment include doxorubicin, ifosfamide, and dacarbazine, either alone or in combination [12-17]. New drugs (pazopanib, trabectedin, and eriblin) have been introduced, but it has not been effective enough to become first-line chemotherapy instead of existing anticancer drugs.

Caffeine (1,3,7-trimethylxanthine) [18] has been shown to induce apoptosis [19-22], overcome chemotherapy- or radiation-induced delays in cell cycle progression [23], and enhance the toxicity of radiation and anticancer agents [24]. In 1989, we developed caffeine-potentiated chemotherapy for malignant bone and soft tissue tumors and subsequently demonstrated the clinical effectiveness of this regimen in clinical use [25-27]. Citrate has been reported to have the ability of the potentiation of anticancer drugs, induction of apoptosis in several cancers other than sarcoma in vitro [28-32]. We designed this study to investigate whether the combination of cisplatin and caffeine citrate show the antitumor effect in sarcoma cell lines in vitro and in vivo.

\section{Methods}

\section{Drugs}

Cisplatin (Wako Pure Chemical Industries, Ltd., Osaka, Japan), caffeine (Wako Pure Chemical Industries, Ltd., Osaka, Japan), and citrate (Wako Pure Chemical Industries, Ltd., Osaka, Japan) and caffeine citrate (Respia, Nobelpharma Co., Ltd. Tokyo, Japan) were used.

\section{Cell lines and culture}

Human osteosarcoma (HOS), human fibrosarcoma (HT1080), and mouse osteosarcoma (LM8) cell lines (American type culture collection, Manassas, VA, USA; Takara bio Inc., Japan) were used in the experiments. All cells were grown in RPMI 1640 medium (Gibco, Grand Island, NY, USA) supplemented with $10 \%$ fetal bovine serum, $100 \mathrm{U} / \mathrm{ml}$ penicillin, and $100 \mu \mathrm{g} / \mathrm{ml}$ streptomycin.

\section{Cell survival assay}

Cell viability was assessed using the WST-8 (4-[3-(4iodophenyl)-2-(4-nitrophenyl)-2H-5-tetrazolio]-1,3-benzene disulfonate) assay kit (cell counting Kit-8, Dojindo laboratory, Mashikimachi, Japan). Briefly, cells were seeded in 96-well flat-bottomed microplates $\left(5 \times 10^{3}\right.$ cells/well), incubated at $37^{\circ} \mathrm{C}$ for $24 \mathrm{~h}$, and exposed to various concentrations of cisplatin $(0,0.125,0.25,0.5$, 1.0 , and $2.0 \mu \mathrm{M}$ ) alone or with the addition of $0.5 \mathrm{mM}$ of caffeine, citrate, or caffeine citrate. Total amount of medium was $200 \mu \mathrm{l} /$ well. At least 4 wells were used for each of the concentrations tested. After incubation with the test compounds for $72 \mathrm{~h}, 10 \mu \mathrm{l}$ WST- 8 solution was added to each well. The microplates were incubated for another $3 \mathrm{~h}$ at $37^{\circ} \mathrm{C}$, and absorption at $450 \mathrm{~nm}$ was measured using a microprocessor-controlled microplate reader (iMark microplate absorbance reader, bio-rad laboratories, Inc., Hercules, CA). The cell-survival fraction was calculated as the percentage of untreated control cells, and the half-maximal inhibitory concentration $\left(\mathrm{IC}_{50}\right)$ values were derived.

\section{Calculation of combination index}

A combination index (CI) assay was performed to test whether the addition of caffeine, citrate, or caffeine citrate enhanced the antitumor effect of cisplatin in the HOS, HT1080, or LM8 cell lines using the CalcuSyn software from ComboSyn Inc. (New Jersey, USA) [33]. CI was calculated by median effect and isobologram methods [34-37]. Synergy was defined as CI $<1.0$, antagonism as $\mathrm{CI}>1.0$, and additive effect at $\mathrm{CI}$ values not significantly different from 1.0.

\section{Cell proliferation assay}

We evaluated cell proliferation following treatment with $0 \mu \mathrm{M}$ or $0.25 \mu \mathrm{M}$ of cisplatin alone or combined with $0.5 \mathrm{mM}$ of caffeine, citrate, or caffeine citrate for 24 h, using a click-iT plus EdU Alexa Fluor 555 imaging kit (Fluoroskan ascent FL; Labsystems, Thermo fisher scientific, Waltham, MA, USA; EdU standing for 5-ethynyl-2-deoxyuridine). Briefly, HOS, HT1080, and LM8 cells were seeded on slide chambers and incubated overnight. After treatment, cells were treated with $\operatorname{EdU}(10 \mathrm{mmol} / \mathrm{L})$ for $1 \mathrm{~h}$. then, they were fixed 
with 4\% paraformaldehyde (Wako pure chemical industries, Itd., Osaka, Japan), washed with $3 \%$ bovine serum albumin in PBS, and permeabilized with $0.5 \%$ triton X-100. Cells were then incubated with the click-iT reaction cocktail, followed by Hoechst 33342 (NucBlue live ReadyProbes reagent, Invitrogen, Carlsbad, CA), and were observed using fluorescence microscope (BZ-9000, Keyence co., Osaka, Japan). EdU-positive cells were scored for cells treated with $0 \mu \mathrm{M}$ of cisplatin or $0.25 \mu \mathrm{M}$ of cisplatin with or without the other compounds. In this assay, results were reported as the mean percentage of EdUpositive cells in five microscopic fields \pm standard deviation $(\mathrm{SD})$.

\section{Mitochondrial depolarization assay}

We evaluated the mitochondrial membrane potential following treatment with $0 \mu \mathrm{M}$ of or $0.25 \mu \mathrm{M}$ of cisplatin alone or combined with $0.5 \mathrm{mM}$ of caffeine, citrate, or caffeine citrate for $24 \mathrm{~h}$ to detect mitochondrial membrane potential. Briefly, HOS, HT1080, and LM8 cells were seeded on slide chambers and incubated overnight. After treatment, unfixed live cells were stained by incubating them with $100 \mathrm{nM}$ tetramethylrhodamine methyl ester (TMRE) (ab113852, Abcam plc, Cambridge, UK) in the dark for $30 \mathrm{~min}$ at $37^{\circ} \mathrm{C}$ in $5 \% \mathrm{CO}_{2}$, followed by Hoechst 33342 (NucBlue live ReadyProbes reagent, Invitrogen, Carlsbad, CA). The cells were washed with PBS and then examined under a fluorescence microscope (BZ-9000, Keyence CO., Osaka, Japan). The results were reported as the mean luminance of one cell in five microscopic fields \pm SD. The luminance was calculated by the analysis application (BZ-II analyzer Ver. 1.42,Keyence co., Osaka, Japan).

\section{Flow cytometry \\ Cell cycle assay}

We evaluated cell cycle profile following treatment with $0 \mu \mathrm{M}$ or $0.25 \mu \mathrm{M}$ of cisplatin alone or combined with $0.5 \mathrm{mM}$ of caffeine, citrate, or caffeine citrate for $72 \mathrm{~h}$, using the MUSE cell cycle kit with the MUSE cell analyzer (Merck Millipore, Billerica, MA, USA) according to the manufacturer's protocol. Briefly, $72 \mathrm{~h}$ after treatment, HOS cell, as a representative cell, was used. Around $1 \times 10^{6}$ cells were transferred to a $2 \mathrm{ml}$ tube. The cells were centrifuged at $300 \times \mathrm{g}$ for $5 \mathrm{~min}$. The cell pellets were washed twice with PBS. The washed cells were fixed with $70 \%$ ethanol. For fixation, cells were incubated for $3 \mathrm{~h}$ at $-20^{\circ} \mathrm{C}$. about $200 \mu \mathrm{l}$ of fixed cells and an equal volume of Muse cell cycle reagent were mixed and incubated for $30 \mathrm{~min}$ at room temperature in dark. Then, cell cycle was analyzed using the kit described above.

\section{Caspase 3/7 activity assay}

Caspase-3/7 activity was evaluated following treatment with $0 \mu \mathrm{M}$ or $0.25 \mu \mathrm{M}$ of cisplatin alone or combined with $0.5 \mathrm{mM}$ of caffeine, citrate, or caffeine citrate for $72 \mathrm{~h}$, using the MUSE Caspase-3/7 kit with the MUSE cell analyzer (Merck Millipore, Billerica, MA, USA) according to the manufacturer's protocol. Briefly, $72 \mathrm{~h}$ after treatment, HOS cell, as a representative cell, was used. Cell samples were incubated with muse Caspase-3/7 working solution in the dark for $30 \mathrm{~min}$ at 37 degrees. Next, the muse 7-AAD working solution was added for $5 \mathrm{~min}$. Samples were read on the muse cell analyzer and results were reported as percentages of live (lower left quadrant), apoptotic (lower right quadrant), apoptotic/ dead (upper right quadrant) and dead (upper left quadrant) cells.

\section{In vivo tumorigenesis assay}

4-week-old female athymic nude mice (Charles River laboratories Japan, INC) were used for the tumorigenesis. LM8 and HT1080 cells were suspended $\left(5 \times 10^{5}\right.$ cells/ $100 \mu \mathrm{l}$ ) in Matrigel (BD bioscience, New Jersey, USA) and injected subcutaneously with a $1.0 \mathrm{ml} 27-\mathrm{G}$ latexfree insulin syringe (Terumo medical corporation, Japan). The mice were assigned to groups (3-4 mice each) and given cisplatin with or without caffeine, citrate, or caffeine citrate with intraperitoneal injections. Physiologic saline was used as a control. A treatment course was given over 1 week, with cisplatin (or saline) administered on day 1 and caffeine, citrate, or caffeine citrate administered on days 2 to 4 , followed by a drug holiday on days 5 to 7 , and we repeated two courses of the treatment with same time course (Fig. 1). We examined three treatment protocols according to our previous study $[38,39]$. The regimen 1 (R1) was composed of cisplatin $(6 \mathrm{mg} / \mathrm{kg}$ body weight), caffeine $(100 \mathrm{mg} / \mathrm{kg})$, citrate $(100 \mathrm{mg} / \mathrm{kg})$, and caffeine citrate $(200 \mathrm{mg} / \mathrm{kg})$. The regimen 2 (R2) was composed of cisplatin $(6 \mathrm{mg} / \mathrm{kg}$ body weight), caffeine $(50 \mathrm{mg} / \mathrm{kg})$, citrate $(50 \mathrm{mg} / \mathrm{kg})$, and caffeine citrate $(100 \mathrm{mg} / \mathrm{kg})$. The regimen 3 (R3) was composed of cisplatin $(3 \mathrm{mg} / \mathrm{kg}$ body weight), caffeine (100 $\mathrm{mg} / \mathrm{kg})$, citrate $(100 \mathrm{mg} / \mathrm{kg})$, and caffeine citrate $(200$ $\mathrm{mg} / \mathrm{kg}$ ). The R2 and R3 were administrated for osteosarcoma cells. Throughout the experiment, all mice were carefully observed daily for adverse events. Another set of mice without implanted tumors were treated with three courses of the R1 to measure changes in body weight. Tumor volume was measured in two dimensions twice a week on days 1 and 4 . Tumor volume $\left(\mathrm{cm}^{3}\right)$ was calculated using the formula: $0.5 \times a^{2} \times b$, where $a$ was the smallest tumor diameter $(\mathrm{cm})$ and $b$ the largest [40]. After two courses of chemotherapy, the mice were euthanized by large amount intraperitoneal injection of 


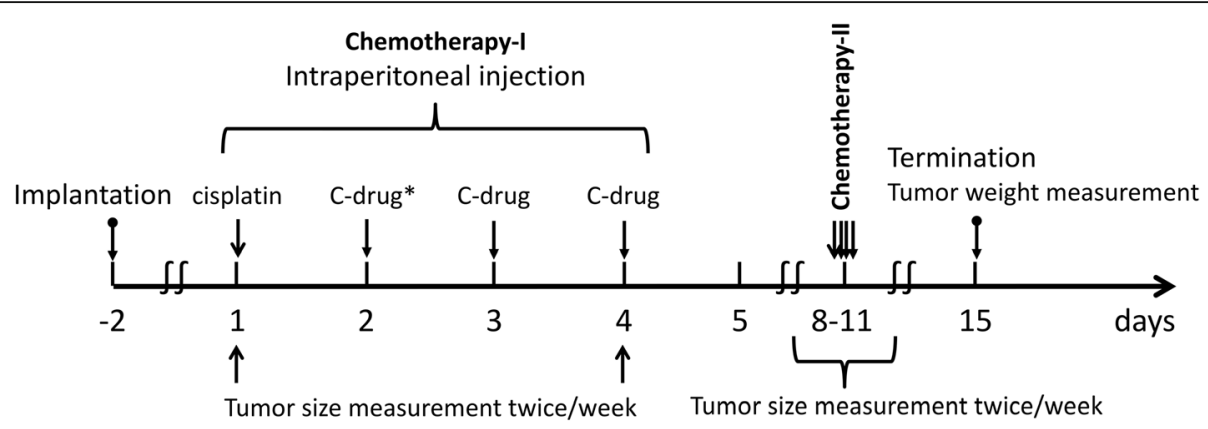

*C-drug: Combination drug (caffeine, citrate, caffeine citrate)

Fig. 1 Treatment scheme. 2 days after tumor cells were injected, chemotherapy was begun. The tumors were measured on days 1 and 4 of each cycle. C-drug, Combination drug: caffeine, citrate, or caffeine citrate
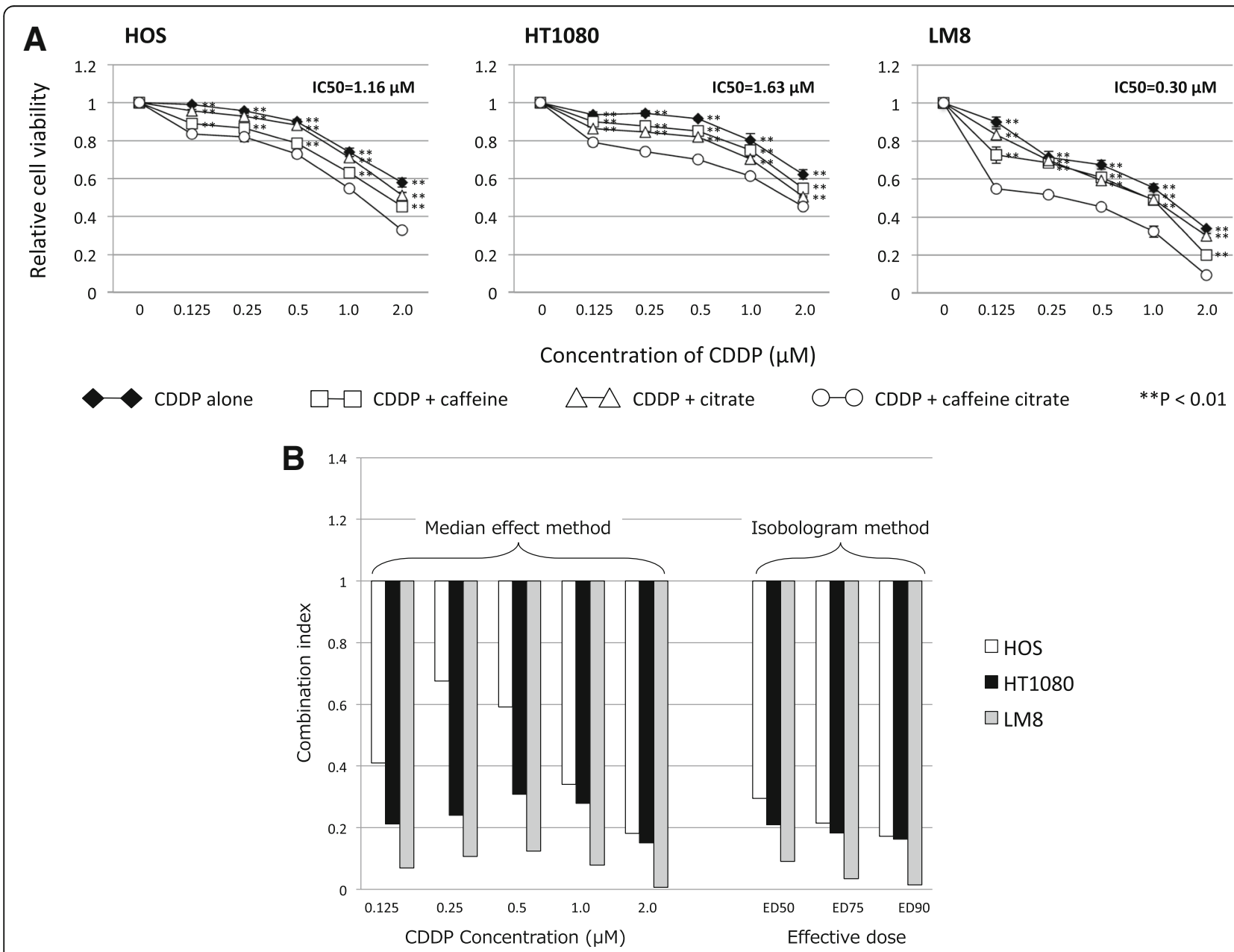

Fig. 2 (a) Effect of caffeine citrate-potentiated chemotherapy on the survival of human (HOS) and mouse (LM8) osteosarcoma cells and human fibrosarcoma cells (HT1080). The cells were treated for $72 \mathrm{~h}$ with physiologic saline as a control or with the indicated concentration of cisplatin (CDDP) alone or combined with caffeine, citrate, or caffeine citrate. Relative numbers of viable cells were measured by the WST-8 assay. Values shown are the means \pm standard deviation of four separate experiments. (b) The combination index values for cisplatin (CDDP) + caffeine citrate were significantly $<1$, indicating a synergistic effect at all CDDP doses in treating human (HOS) and mouse (LM8) osteosarcoma cells and human fibrosarcoma cells (HT1080) 
pentobarbital sodium and the tumors removed and weighed.

All animal experiments were undertaken in accordance with the Guidelines for the Care and Use of Laboratory Animals under the National Institutes of Health assurance number A3873-01 and the U.S. Public Health Service Policy on Humane Care and Use of Laboratory Animals [41], which correspond to national guidelines in Japan [42]. The humane endpoint of the maximum tumor size was set which was not exceed $10 \%$ of normal body weight according (Institutional Animal Care and Use Committee) guidelines [43]. The protocol was approved by the Institute for Experimental Animals, Kanazawa University Advanced Science Research Center.

\section{Statistical analysis}

The data were statistically compared by the ANOVA using Statcel 3 (the Publisher OMS ltd., Tokyo, Japan). A $p$ value of $<0.05$ was considered statistically significant.

\section{Results}

Effect of cisplatin and combinations on cell survival and combination index

We examined the effect of cisplatin combined with the other compounds on tumor cell survival. The viability of all cells was inhibited by cisplatin, cisplatin + caffeine, cisplatin + citrate, and cisplatin + caffeine citrate with a dose-dependent manner (Fig. 2a). $I_{50}$ values at $72 \mathrm{~h}$ after administration of cisplatin + caffeine citrate for HOS, HT1080, and LM8 cells were $1.16 \mu \mathrm{mol} / \mathrm{l}, 1.63 \mu \mathrm{mol} / \mathrm{l}$, and $0.30 \mu \mathrm{mol} / \mathrm{l}$, respectively. In both the median effect and isobologram methods, the CI value was less than 1.0, thereby demonstrating synergy between caffeine citrate and cisplatin at almost all tested concentrations in HOS, HT1080, LM8 cells (Fig. 2b).

\section{Effect of cisplatin and combinations on cell proliferation}

In EdU assay, cisplatin + caffeine citrate resulted in a significant decrease in EdU-positive proliferating cells in the HOS, HT1080, and LM8 cells (Fig. 3). In HOS cells, EdU-positive

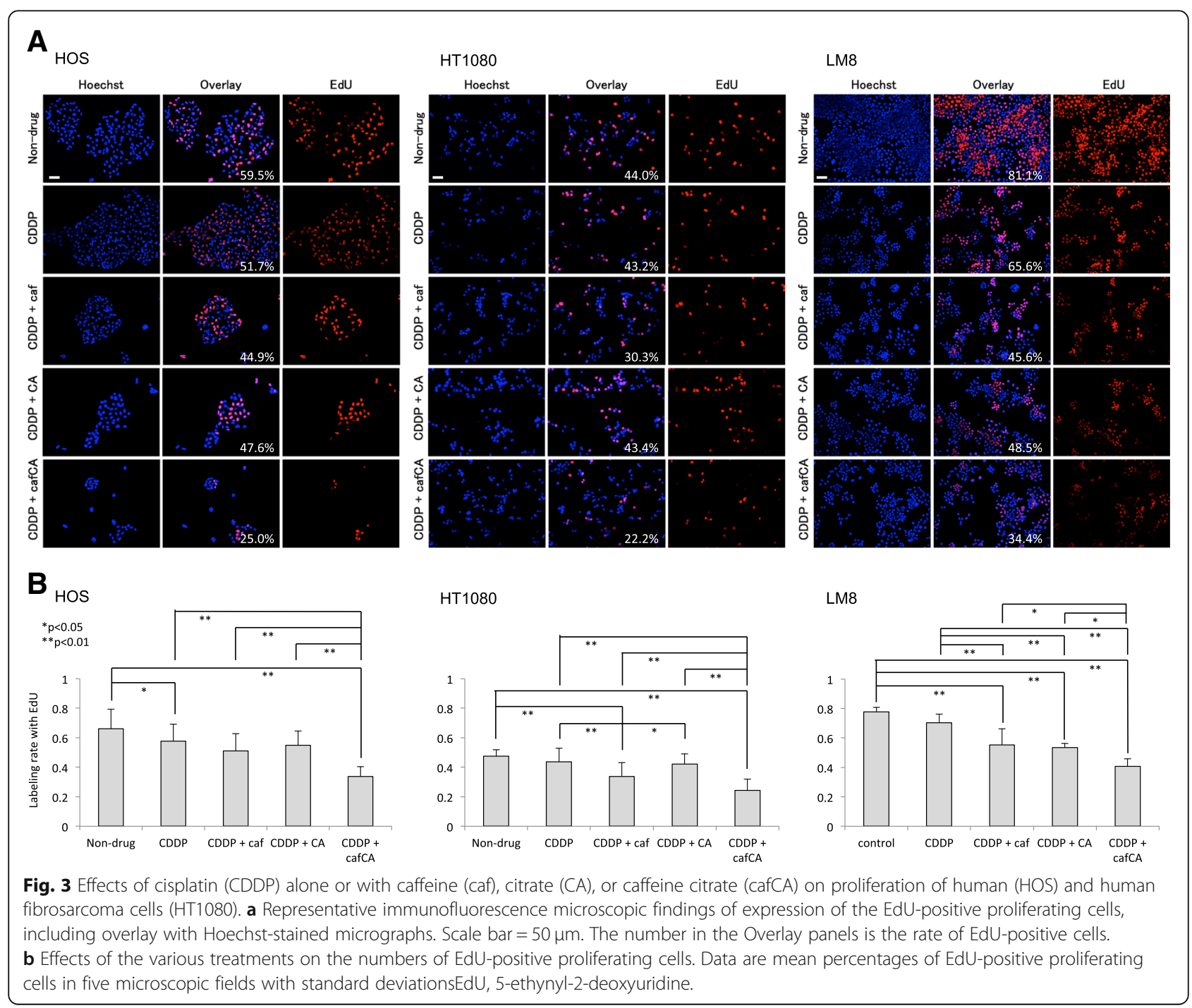


cells were significantly decreased in cisplatin + caffeine and cisplatin + caffeine citrate relative to the control group, and in cisplatin + caffeine citrate relative to all other treatment groups. In HT1080 cells, EdU-positive cells were significantly decreased in cisplatin + caffeine/caffeine citrate relative to the control group, in cisplatin + caffeine relative to cisplatin and cisplatin + citrate, and in cisplatin + caffeine citrate relative to all other treatment groups. In LM8 cells, EdU-positive cells were significantly decreased in cisplatin + caffeine/citrate/caffeine citrate relative to the control group and cisplatin, and in cisplatin + caffeine citrate relative to all other treatment groups.

\section{Effect of cisplatin and combinations on mitochondrial membrane potential}

In mitochondrial depolarization assay, cisplatin + caffeine citrate significantly decreased cell luminance, indicating a weaker mitochondrial membrane potential in the HOS, HT1080, and LM8 cells (Fig. 4). In HOS cells, the cell luminance was significantly decreased in all treatment groups relative to the control group, and in cisplatin + caffeine citrate relative to all other treatment groups. In HT1080 cells, the cell luminance was significantly decreased in cisplatin + caffeine/citrate/caffeine citrate relative to the control group and cisplatin alone, and in cisplatin + caffeine citrate relative to cisplatin + caffeine/ citrate. In LM8 cells, the cell luminance was significantly decreased in all treatment groups relative to the control group, in cisplatin + caffeine/citrate/caffeine + citrate relative to cisplatin alone, and cisplatin + caffeine citrate relative to isplatin + caffeine.

Effect of cisplatin and combinations on cell cycle profile After treatment with cisplatin alone, G2/M fraction was significantly increased, indicating G2/M arrest. After treatment with cisplatin + caffeine, cisplatin + citrate, and cisplatin + caffeine citrate, G2/M fraction was also significantly increased, compared with control group.
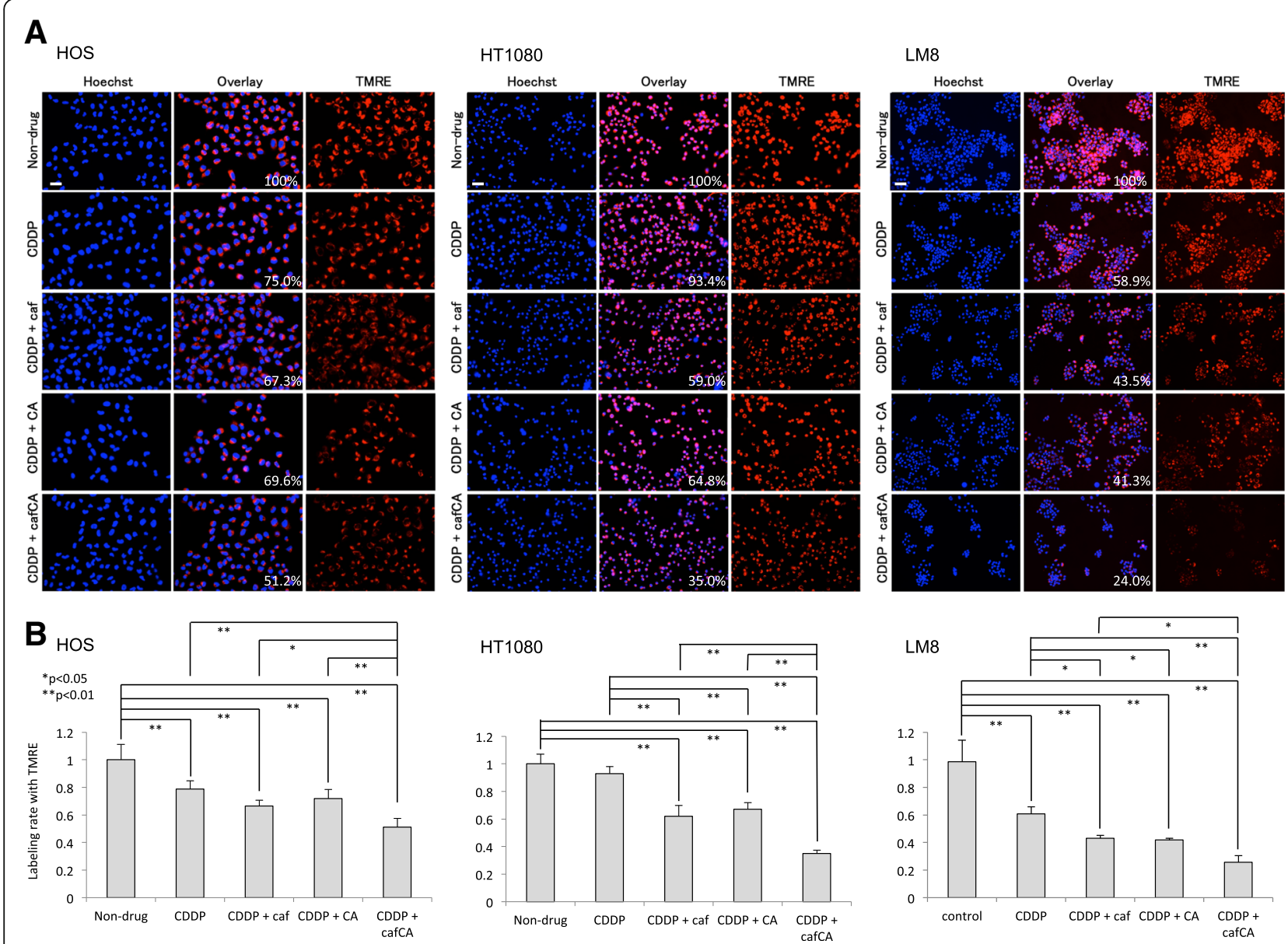

Fig. 4 Effects of cisplatin (CDDP) alone or with caffeine (caf), citrate (CA), or caffeine citrate (cafCA) on apoptosis of human (HOS) and human fibrosarcoma cells (HT1080). a Representative immunofluorescence microscopic findings of mitochondrial membrane potential expression. Scale bar = 50 $\mu$ m. The number in the Overlay panels shows the intensity of luminance per cell when the non-drug is based on $100 \%$. $\mathbf{b}$ Effects of various treatments on the mean luminance of mitochondrial membrane potential. Data are mean luminance of mitochondrial membrane potential in five microscopic fields with standard deviations. TMRE, tetramethylrhodamine methyl ester 
However, G2/M fraction was significantly decreased, compared with cisplatin alone. These results indicated that the combined treatment with cisplatin proceeded to G0/G1 from G2/M arrest. Moreover, after treatment (all conditions), G0/G1 fraction was significantly decreased, compared with control group, and after treatment with cisplatin + combination drugs, G0/G1 fraction was significantly increased, compared with treatment with cisplatin alone. In $\mathrm{S}$ fraction, there was significant differences between control and treatment group, and there was no significant differences between treatment with cisplatin alone and cisplatin + combination drugs. These results indicated that the combination drugs induced G0/G1 arrest. Finally, caffeine citrate had the significantly strong effect compare to the combine with caffeine or citrate (Fig. 5).

\section{Effect of cisplatin and combinations on caspase 3/7 activity}

Most of the cells were classified into live and apoptotic cells among live, apoptotic, apoptotic/dead, and dead cells (Fig. 6a). In the rate of live cells, control group was significantly higher than all other treatment group. After treatment with cisplatin + caffeine citrate, the rate of live cells was significantly lower, compared with any other treatment group. After treatment with cisplatin + caffeine and cisplatin + citrate, the rate of live cells was also significantly lower, compared with cisplatin alone. In the rate of apoptotic cells, control group was significantly lower than all other treatment group. After treatment with cisplatin + caffeine citrate, the rate of live cells was significantly higher, compared with any other treatment group. After treatment with cisplatin + caffeine and cisplatin + citrate, the rate of live cells was also significantly lower, compared with cisplatin alone (Fig. 6b).

\section{Effect of cisplatin and combinations on mouse tumors}

2 days after implantation of LM8 mouse osteosarcoma or HT1080 human fibrosarcoma cells, the mice were treated with chemotherapy by intraperitoneal injection 2 times a week for 2 weeks. Cisplatin + caffeine citrate significantly reduced tumor volume and tumor weight in both LM8 and HT1080 by R1 protocol. Especially, the volume of HT1080-tumor treated with cisplatin +

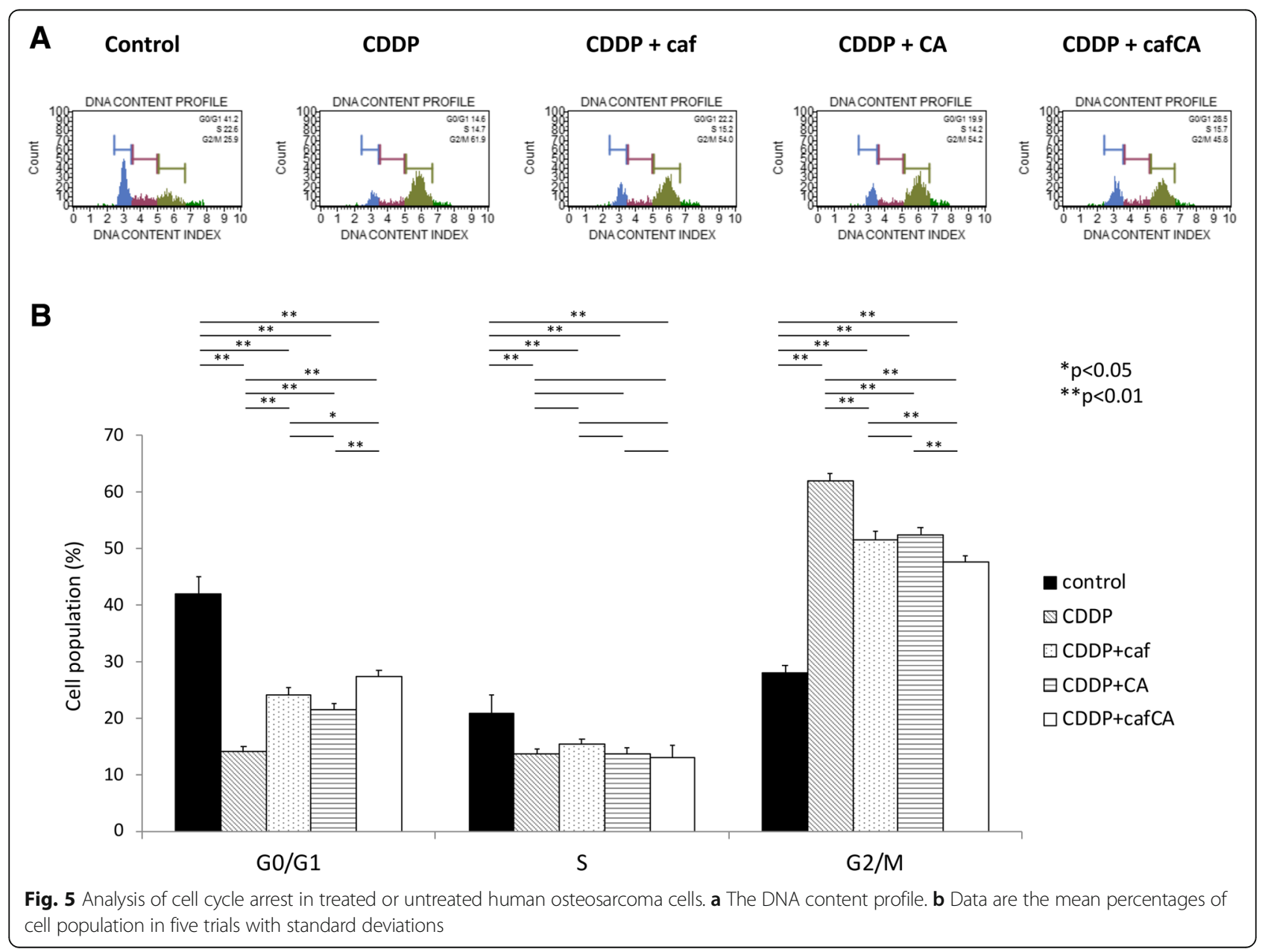




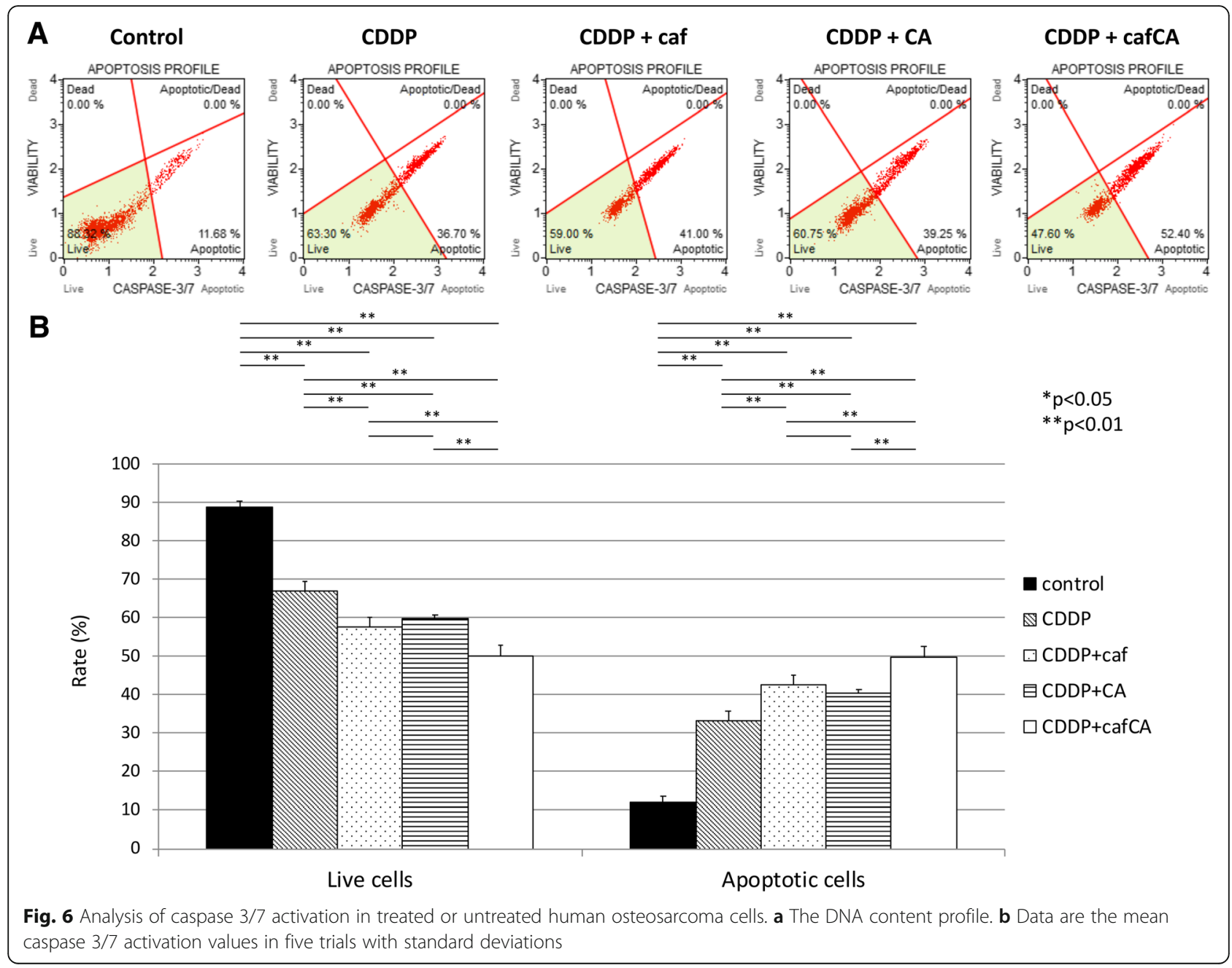

caffeine citrate was significantly smaller than with all other treatment (Fig. 7a). The five groups of mice without implanted tumors had no significant differences in body weight after three courses of the R1 chemotherapy regimens (Fig. 7b). In the results of R2 regimen for LM8, the volume and weight of the tumor treated with caffeine + citrate was significantly reduced, compared with control group. There was no significant difference, but compared with other treatments, it was able to suppress the tumor volume and weight (Additional file 1: Figure $\mathrm{S} 1 \mathrm{~A})$. In the results of R3 regimen for LM8, the volume and weight of the tumor treated with caffeine + citrate was also significantly reduced, compared with control group. Like R2 regimen, there was no significant difference, but compared with other treatments, it was able to suppress the tumor volume and weight (Additional file 1: Figure S1B).

\section{Discussion}

In this study, we found that chemotherapy with cisplatin + caffeine citrate suppressed osteosarcoma and fibrosarcoma cell proliferation and enhanced apoptosis as compared with cisplatin alone or with the addition of either caffeine or citrate. The effect of caffeine citrate was synergistic, not just additive. We also demonstrated that cisplatin + caffeine citrate had a significantly greater inhibition of tumor growth than the other treatments given to mice with implanted osteosarcomas or fibrosarcomas.

Caffeine inhibits DNA repair induced by cisplatin and increases the anticancer effects of cisplatin [44]. Mechanisms responsible for the influence of caffeine on the anticancer effects of cisplatin have been suggested to involve several proteins, such as ATR kinase, ataxia telangiectasia mutated (ATM) kinase, and p53 unregulated modulator of apoptosis (PUMA) [45, 46]. Caffeine overcomes the cisplatinum-induced S/G2 cell-cycle arrest with subsequent increased apoptosis. Cell-cycle arrest is a survival mechanism in chemotherapy-treated cells, and progression of the cell cycle induced by caffeine resensitizes cancer cells to chemotherapy [47]. In this study, caffeine was stronger, overcame the cisplatinum-induced S/G2 cell-cycle arrest with subsequent increased 


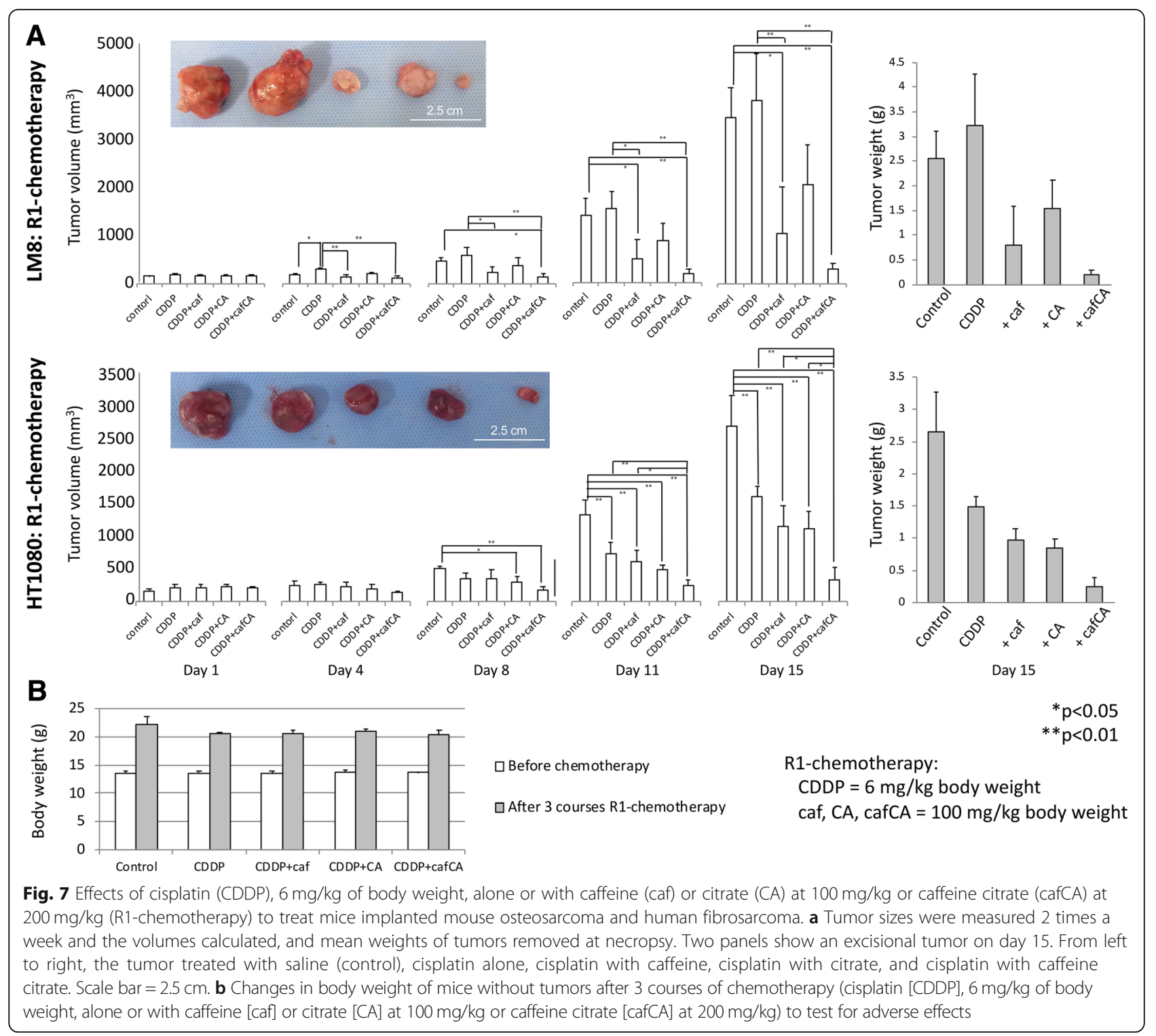

apoptosis in HOS. Moreover, caffeine induced G0/G1 cell-cycle arrest and this result suggested that caffeine also suppressed cell proliferation.

Citrate leads to an early decrease in the expression of the anti-apoptotic protein Mcl-1, a molecule that plays a key role together with the protein $\mathrm{Bcl}-\mathrm{xL}$ in the chemoresistance of certain cancers [28, 29], particularly mesothelioma [30]. The addition of citrate to Bcl-xL-expressing cells may lead to increased protein $\mathrm{N}$-alpha-acetylation and sensitization of those cells to apoptosis [31]. The mechanism explaining the sensitization to chemotherapy of citrate-exposed cells remains to be investigated [32]. These findings are mainly from in vitro studies of cells and there are few studies with cell cycle. None have been done using sarcoma cell lines nor are there clinical studies of the effects of adding citrate to chemotherapy. In this study, citric acid also overcame the cisplatinuminduced S/G2 cell-cycle arrest with subsequent increased apoptosis and induced G0/G1 cell-cycle arrest with subsequent suppressed cell proliferation. Cancer cells depend on both glycolysis system and citric acid cycle [48], so we have to continue research on cancer metabolism in the future.

Finally, caffeine citrate had most strong effect as a combination drug than caffeine and citric acid in both overcoming the cisplatinum-induced S/G2 cell-cycle arrest with subsequent increased apoptosis and inducing G0/G1 cell-cycle arrest with subsequent suppressed cell proliferation.

This study also demonstrated an in vitro effect of caffeine citrate potentiating cisplatin. It is intriguing is that 
this was a synergistic effect, better than that of cisplatin combined with either caffeine or citrate. The separate mechanisms described above by which caffeine and citrate enhance an antitumor effect may have played a role in our findings in this study but that does not account for the synergistic effect of caffeine citrate. In addition to those findings in vitro, we have also demonstrated caffeine citrate's value when added to cisplatin in the in vivo mouse model for both osteosarcoma and fibrosarcoma.

As a limitation, caffeine monotherapy and citrate monotherapy have not been evaluated, and only one kind of cell (HOS) was used in flow cytometry.

\section{Conclusions}

This is the first report demonstrating that caffeine citrate has a significantly greater potentiating effect on cisplatin than adding either caffeine or citric acid. Further investigation is of course required before this can be tested clinically, but the combination of cisplatin with caffeine citrate is a novel treatment that might hold promise for improving the outcome of osteosarcoma and fibrosarcoma, which up till now has generally not responded well to chemotherapy. It would also be worthwhile evaluating whether caffeine citrate might potentiate chemotherapy for other types of cancer.

\section{Additional files}

Additional file 1: Figure S1. The results of $R 2$ and $R 3$ regimen for $L M 8$. Effects of cisplatin (CDDP), $6 \mathrm{mg} / \mathrm{kg}$ of body weight, alone or with caffeine (caf) or citrate (CA) at $50 \mathrm{mg} / \mathrm{kg}$ or caffeine citrate (cafCA) at 100 $\mathrm{mg} / \mathrm{kg}$ (R2-chemotherapy) and cisplatin (CDDP), $3 \mathrm{mg} / \mathrm{kg}$ of body weight, alone or with caffeine (caf) or citrate (CA) at $100 \mathrm{mg} / \mathrm{kg}$ or caffeine citrate (cafCA) at $200 \mathrm{mg} / \mathrm{kg}$ (R3-chemotherapy) to treat mice implanted mouse osteosarcoma. Tumor sizes were measured 2 times a week and the volumes calculated, and mean weights of the tumors removed at necropsy. (PDF $466 \mathrm{~kb}$ )

Additional file 2: Table S1. The information on quantitative changes. (XLSX $19 \mathrm{~kb})$

\section{Abbreviations \\ CA: Citrate; caf: Caffeine; cafCA: Caffeine citrate; CDDP: Cisplatin; $\mathrm{Cl}$ : Combination index; EdU: 5-ethynyl-2-deoxyuridine; $\mathrm{IC}_{50}$ : Half-maximal inhibitory concentration; TMRE: Tetramethylrhodamine methyl ester; WST- 8: 4-[3-(4-iodophenyl)-2-(4-nitrophenyl)-2H-5-tetrazolio]-1,3-benzene disulfonate}

\section{Acknowledgments}

We are grateful to Dr. Shinji Miwa, Dr. Kentaro Igarashi, Dr. Hiroyuki Inatani, Dr. Yu Aoki, Dr. Takashi Higuchi, Dr. Yuta Taniguchi, Dr. Hirotaka Yonezawa, Dr. Yoshihiro Araki, and Dr. Hisaki Aiba for helpful discussions.

\section{Authors' contributions}

All authors read and approved the final manuscript. Conception and design: KA, NY, AT, HT. Development of methodology: KA, AT. Acquisition of data (provided animals, acquired and managed patients, provided facilities, etc.): KA, AT. Analysis and interpretation of data (e.g., statistical analysis, biostatistics, computational analysis): KA, NY, KH, AT, HT. Writing, review, and/or revision of the manuscript: KA, NY, KH, AT, HT. Administrative, technical, or material support (i.e., reporting or organizing data, constructing databases): KA, NY, KH, AT. Study supervision: NY, KH, AT, HT

Funding

Not applicable.

\section{Availability of data and materials}

The datasets generated and analyzed during the current study are not publicly available because we will continue to use them for future research but are available from the corresponding author on reasonable request. The information on quantitative changes is included in Additional file 2: Table S1

Ethics approval and consent to participate

All animal experiments were undertaken according to the national guideline in Japan. The protocol was approved by the Institute for Experimental Animals, Kanazawa University Advanced Science Research Center.

\section{Consent for publication}

Not applicable.

\section{Competing interests}

The authors declare that they have no competing interests.

Received: 5 February 2019 Accepted: 28 June 2019

Published online: 15 July 2019

\section{References}

1. Mirabello L, Troisi RJ, Savage SA. International osteosarcoma incidence patterns in children and adolescents, middle ages and elderly persons. Int J Cancer. 2009:1:229-34.

2. Isakoff MS, Bielack SS, Meltzer P, Gorlick R. Osteosarcoma. Current treatment and a collaborative pathway to success. J Clin Oncol. 2015;33:3029-35.

3. Bacci G, Ferrari S, Lari S, Mercuri M, Donati D, Longhi A, Forni C, Bertoni F, Versari M, Pignotti E. Osteosarcoma of the limb: amputation or limb salvage in patients treated by neoadjuvant chemotherapy. J Bone Joint Surg Br. 2002;84:88-92.

4. Muscolo DL, Ayerza MA, Aponte-Tinao LA, Ranalletta M. Partial epiphyseal preservation and intercalary allograft reconstruction in high-grade metaphyseal osteosarcoma of the knee. J Bone Joint Surg Am. 2002;86: 2686-93.

5. Hughes DP. Strategies for the targeted delivery of therapeutics for osteosarcoma. Expert Opin Drug Deliv. 2009;6:1311-21.

6. Rasalkar DD, Chu WC, Lee V, Paunipagar BK, Cheng FW, Li CK. Pulmonary metastases in children with osteosarcoma: characteristics and impact on patient survival. Pediatr Radiol. 2011:2:227-36.

7. Lewis VO. What's new in musculoskeletal oncology. J Bone Joint Surg Am. 2007:89:1399-407.

8. Schffski P, Cornillie J, Wozniak A, Li H, Hompes D. Soft tissue sarcoma: an update on systemic treatment options for patients with advanced disease. Oncol Res Treat. 2014;37:355-62. https://doi.org/10.1159/000362631.

9. Fletcher CDM, Bridge JA, Hogendoorn PCW, Mertens F, editors. WHO classification of tumours of soft tissue and bone. 4th ed. Lyon: IARC; 2013.

10. von Mehren M, Randall RL, Benjamin RS, Boles S, Bui MM, Conrad EU 3rd, Ganjoo KN, George S, Gonzalez RJ, Heslin MJ, Kane JM 3rd, Koon H, Mayerson J, McCarter M, McGarry SV, Meyer C, O'Donnell RJ, Pappo AS, Paz IB, Petersen IA, Pfeifer JD, Riedel RF, Schuetze S, Schupak KD, Schwartz HS, Tap WD, Wayne JD, Bergman MA, Scavone J. Soft tissue sarcoma, version 2. 2016, NCCN clinical practice guidelines in oncology. J Natl Compr Cancer Netw. 2016;14:758-86

11. Stiller CA, Trama A, Serraino D, et al. RARECARE working group. Descriptive epidemiology of sarcomas in Europe: report from the RARECARE project. Eur J Cancer. 2013;49:684-95. https://doi.org/10.1016/j.ejca.2012.09.011.

12. Elias A, Ryan L, Sulkes A, Collins J, Aisner J, Antman KH. Response to mesna, doxorubicin, ifosfamide, and dacarbazine in 108 patients with metastatic or unresectable sarcoma and no prior chemotherapy. J Clin Oncol. 1989;7: 1208-16. https://doi.org/10.1200/JCO.1989.7.9.1208.

13. Antman K, Crowley J, Balcerzak SP, et al. An intergroup phase III randomized study of doxorubicin and dacarbazine with or without ifosfamide and mesna in advanced soft tissue and bone sarcomas. J Clin Oncol. 1993:11: 1276-85. https://doi.org/10.1200/JCO.1993.11.7.1276. 
14. Edmonson $\mathrm{JH}$, Ryan $\mathrm{LM}$, Blum $\mathrm{RH}$, et al. Randomized comparison of doxorubicin alone versus ifosfamide plus doxorubicin or mitomycin doxorubicin, and cisplatin against advanced soft tissue sarcomas. J Clin Oncol. 1993;11:1269-75. https://doi.org/10.1200/JCO.1993.11.7.1269.

15. Santoro A, Tursz T, Mouridsen $H$, et al. Doxorubicin versus CYVADIC versus doxorubicin plus ifosfamide in first-line treatment of advanced soft tissue sarcomas: a randomized study of the European Organization for Research and Treatment of Cancer soft tissue and bone sarcoma group. J Clin Oncol. 1995;13:1537-45. https://doi.org/10.1200/JCO.1995.13.7.1537.

16. Judson I, Verweij J, Gelderblom H, et al. Doxorubicin alone versus intensified doxorubicin plus ifosfamide for first-line treatment of advanced or metastatic soft-tissue sarcoma: a randomised controlled phase 3 trial. Lancet Oncol. 2014;15:415-23. https://doi.org/10.1016/S1470-2045(14)70063-4

17. Martin-Broto J, Pousa AL. de las Peñas R, et al. randomized phase II study of trabectedin and doxorubicin compared with doxorubicin alone as first-line treatment in patients with advanced soft tissue sarcomas: a Spanish Group for Research on sarcoma study. J Clin Oncol. 2016;34:2294-302. https://doi. org/10.1200/JCO.2015.65.3329.

18. IARC working group on the evaluation of carcinogenic risks to humans. Coffee, tea, mate, methylxanthines and methylglyoxal. IARC Monogr Eval Carcinog Risks Hum. 1991;51:1-513.

19. Levi-Schaffer F, Touitou E. Xanthines inhibit $3 T 3$ fibroblast proliferation. Skin Pharmacol. 1991;4:286-90.

20. Miwa S, Sugimoto N, Shirai T, Hayashi K, Nishida H, Ohnari I, Takeuchi A, Yachie A, Tsuchiya $\mathrm{H}$. Caffeine activates tumor suppressor PTEN in sarcoma cells. Int J Oncol. 2011;39:465-72.

21. Miwa S, Sugimoto N, Yamamoto N, Shirai T, Nishida H, Hayashi K, Kimura H, Takeuchi A, Igarashi K, Yachie A, Tsuchiya H. Caffeine induces apoptosis of osteosarcoma cells by inhibiting AKT/mTOR/S6K, NF-KB and MAPK pathways. Anticancer Res. 2012;32:3643-9.

22. He Z, Ma WY, Hashimoto T, Bode AM, Yang CS, Dong Z. Induction of apoptosis by caffeine is mediated by the p53, Bax, and caspase 3 pathways. Cancer Res. 2003;63:4396-401.

23. Lau CC, Pardee AB. Mechanism by which caffeine potentiates lethality of nitrogen mustard. Proc Natl Acad Sci U S A. 1982;79:2942-6.

24. Busse PM, Bose SK, Jones RW, Tolmach LJ. The action of caffeine on $\mathrm{x}$ irradiated hela cells. lii. Enhancement of x-rayinduced killing during g2 arrest. Radiat Res. 1978;76:292-307.

25. Tsuchiya H, Tomita K, Mori Y, Asada N, Yamamoto N. Marginal excision for osteosarcoma with caffeine assisted chemotherapy. Clin Orthop. 1999;358:27-35.

26. Tsuchiya H, Yasutake H, Yokogawa A, Baba H, Ueda Y, Tomita K. Effect of chemotherapy combined with caffeine for osteosarcoma. J Cancer Res Clin Oncol. 1992:118:567-9.

27. Tsuchiya H, Tomita K, Mori Y, Asada N, Morinaga T, Kitano S, Yamamoto N. Caffeine-assisted chemotherapy and minimized tumor excision for nonmetastatic osteosarcoma. Anticancer Res. 1998;18:657-66.

28. Willis SN, Chen L, Dewson G, Wei A, Naik E, Fletcher Jl, Adams JM, Huang DC. Proapoptotic Bak is sequestered by $\mathrm{MCl}-1$ and $\mathrm{BCl}-\mathrm{xL}$, but not $\mathrm{BCl}-2$, until displaced by BH3-only proteins. Genes Dev. 2005;19:1294-305.

29. Warr MR, Shore GC. Unique biology of Mcl-1: therapeutic opportunities in cancer. Curr Mol Med. 2008;8:138-47.

30. Varin E, Denoyelle $C$, Brotin E, Meryet-Figuière $M$, Giffard F, Abeilard E, Goux D, Gauduchon P, Icard P, Poulain L. Downregulation of BCl-xL and $\mathrm{MCl}-1$ is sufficient to induce cell death in mesothelioma cells highly refractory to conventional chemotherapy. Carcinogenesis. 2010;31:984-93.

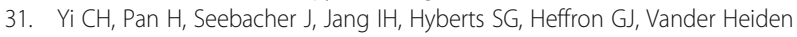
MG, Yang R, Li F, Locasale JW, Sharfi H, Zhai B, Rodriguez-Mias R, Luithardt H, Cantley LC, Daley GQ, Asara JM, Gygi SP, Wagner G, Liu CF, Yuan J. Metabolic regulation of protein $\mathrm{N}$-alpha-acetylation by $\mathrm{BCl}-\mathrm{XL}$ promotes cell survival. Cell. 2011;146(4):607.

32. Zhang $X$, Varin E, Allouche S, Lu Y, Poulain L, Icard P. Effect of citrate on malignant pleural mesothelioma cells: a synergistic effect with cisplatin. Anticancer Res. 2009;29:1249-54.

33. Chou TC, Martin N. CompuSyn for drug combinations: PC software and User's guide: a computer program for quantitation of synergism and antagonism in drug combinations, and the determination of IC50 and ED50 and LD50 values. Paramus, NJ, USA: ComboSyn Inc; 2005.

34. Chou T-C. Drug combination studies and their synergy quantification using the Chou-Talalay method. Cancer Res. 2010;70:440-6.

35. Tallarida RJ, Porreca F, Cowan A. Statistical analysis of drug-drug and sitesite interactions with isobolograms. Life Sci. 1989;45:947-61.
36. Roering SC, Fujimoto JM. Morphine antinociception in different strains of mice: relationship of supraspinal-spinal multiplicative interaction to tolerance. J Pharmacol Exp Ther. 1988;247:603-8.

37. Tallarida RJ. Drug synergism and dose-effect data analysis. Florida, USA: Chapman \& Hall/CRC; 2000.

38. Tsuchiya $\mathrm{H}$. Enhancement of the effect of anticancer agents by combined use of caffeine. Juzen Med Soc. 1988;97:543-56.

39. Igarashi K, Kawaguchi K, Kiyuna T, Murakami T, Yamamoto N, Hayashi K, Kimura $H$, Miwa S, Tsuchiya H, Hoffman RM. Antimetastatic efficacy of the combination of caffeine and valproic acid on an orthotopic human osteosarcoma cell line model in nude mice. Anticancer Res. 2017;37:1005-11.

40. Sun FX, Tohgo A, Bouvet M, Yagi S, Nassirpour R, Moossa AR, Hoffman RM Efficacy of comptothecin analog DX-8951f (Exatecan Mesylate) on human pancreatic cancer in an orthotopic metastatic model. Cancer Res. 2003;63: 80-5.

41. Guide for the care and use of laboratory animals. National Academies Press. 8th ed; 2011. http://grants.nih.gov/grants/olaw/Guide-for-the-Care-and-Useof-Laboratory-Animals.pdf. Accessed 13 Jun 2017

42. Kosaka K. Ministry of Education, culture, sports, science and technology, notice no.71. Reserch promotion bureau, life sciences divisions. 2006. http:// www.lifescience.mext.go.jp/policies/pdf/an_material011.pdf. Accessed 13 Jun 2017.

43. ARENA/OLAW [Applied Research Ethics National Association (DHHS/NIH)/ Office of Laboratory Animal Welfare]. Institutional animal care and use committee guidebook. 2nd ed. 2002. Washington DC: DHHS. P.107. https:// grants.nih.gov/grants/olaw/guidebook.pdf. Accessed 13 Jun 2017.

44. Kawano Y, Nagata M, Kohno T, Ichimiya A, Iwakiri T, Okumura M, Arimori K. Caffeine increases the antitumor effect of cisplatin in human hepatocellular carcinoma cells. Biol Pharm Bull. 2012;35:400-7.

45. Sarkaria JN, Busby EC, Tibbetts RS, Roos P, Taya Y, Karnitz LM, Abraham RT. Inhibition of ATM and ATR kinase activeties by the radiosensitizing agent, caffeine. Cancer Res. 1999;59:4375-82.

46. Wang G, Bhoopalan V, Wang D, Wang L, Xu X. The effect of caffeine on cisplatin-induced apoptosis of lung cancer cells. Exp Hematol Oncol. 2015;4 5. https://doi.org/10.1186/2162-3619-4-5.

47. Miwa S, Yano S, Tome Y, Sugimoto N, Hiroshima Y, Uehara F, Mii S, Kimura $H$, Hayashi K, Efimova EV, Fujiwara T, Tsuchiya H, Hoffman RM. Dynamic color-coded fluorescence imaging of the cell-cycle phase, mitosis, and apoptosis demonstrates how caffeine modulates cisplatinum efficacy. J Cell Biochem. 2013;114:2454-60.

48. Gatenby RA, Gillies RJ. Why do cancers have high aerobic glycolysis? Nat Rev Cancer. 2004;4:891-9. https://doi.org/10.1038/nrc1478.

\section{Publisher's Note}

Springer Nature remains neutral with regard to jurisdictional claims in published maps and institutional affiliations.

\section{Ready to submit your research? Choose BMC and benefit from:}

- fast, convenient online submission

- thorough peer review by experienced researchers in your field

- rapid publication on acceptance

- support for research data, including large and complex data types

- gold Open Access which fosters wider collaboration and increased citations

- maximum visibility for your research: over $100 \mathrm{M}$ website views per year

At $\mathrm{BMC}$, research is always in progress.

Learn more biomedcentral.com/submissions 